\title{
SELECTED PROPERTIES OF MACASSAR EBONY (DIOSPIROS CELEBICA) FROM PLANTATION
}

\author{
Darmawan $\mathrm{W}^{1, *}$, Rahayu $\mathrm{I}^{1}$, Lumongga $\mathrm{D}^{2}$, Putri $\mathrm{RL}^{3}$, Mubarok $\mathrm{M}^{4}$ \& Gérardin $\mathrm{P}^{4}$ \\ ${ }^{1}$ Department of Forest Products, Faculty of Forestry, Bogor Agricultural University (IPB), Bogor, 16680 Indonesia \\ ${ }^{2}$ Faculty of Agriculture, Muhammadiyah University, Purwokerto, 53182 Indonesia \\ ${ }^{3}$ Universitas Islam Balitar, Blitar, 66137 Indonesia \\ ${ }^{4}$ Laboratory of Studies and Research on Wood Material (LERMAB), The University of Lorraine, 54000 Nancy, France \\ *wayandar@indo.net.id
}

Submitted January 2020, accepted June 2020

\begin{abstract}
Macassar ebony (Diospyros celebica) wood plantation is cultivated in Indonesia by the government as well as some communities. However the properties of the planted ebony are yet to be investigated. Thus, the purpose of this study was to investigate the proportion of juvenile and mature wood of ebony and to analyse its radial features from pith to bark, based on density, shrinkage, static bending in modulus of rupture and modulus of elasticity, fibre length, microfibril angle and natural durability. A segmented modeling approach was used to find the juvenile mature transition. Laboratory test was performed to characterise termite and decay fungi resistances from pith to bark of Macassar ebony. Maturation of Macassar ebony was estimated to start at radial increments of $9 \mathrm{~cm}$ from the pith, both by fibre length and microfibril angle. Projected figure of the proportion of juvenile wood in Macassar ebony was around $34 \%$. The results also indicated that the Macassar ebony wood was $843.3 \mathrm{~kg} \mathrm{~m}^{-3}$ in density, 1.44 in coefficient of anisotropy (good stability), 10317.5 MPa in modulus of elasticity and 98.0 MPa in modulus of rupture. Natural durability of Macassar ebony against termite and decay fungi was rated to be class I (very durable). Toxic coumpounds analysed by gas chromatography-mass spectrometry (GCMS) and nuclear magnetic resonance (NMR) were dimethoxymethylnaphthol, dimethoxymetylnaphtol trimethylsilane and gallic acid trimethylsilane.
\end{abstract}

Keywords: Macassar ebony wood, juvenile and mature, bending strength, natural durability, toxic extractive compounds

\section{INTRODUCTION}

The precious wood species of the genera Diospyros play a critical role in ecosystems across its widespread range in tropical areas. Besides timber products, the species of this genera also provide significant economic resources, such as non-timber forest products, and have high horticultural value. The genus Diospyros consists of approximately 735 species worldwide that provide essential ecosystem services for fruit dispersers), including birds, mammals, and even reptiles (Wallnöfer 2001, Griffiths et al. 2011, Beech et al. 2016). Different parts of Diospyros species have medicinal properties and are used to treat urinary infections, skin and blood diseases, and as antibiotics to treat syphilis and malaria (Orwa et al. 2009).

Diospyros has wide distribution range in South East Asia including Indo-China, Burma, Thailand, Peninsular Malaysia, Indonesia, Brunei and New Guinea. Diospyros celebica
(Macassar ebony) is an important source of hardwood tree species in Indonesia. Maccasar ebony is only indigenous in Sulawesi between $02^{\circ} 36^{\prime}-05^{\circ} 11^{\prime} S$ latitude and $119^{\circ} 40^{\prime}-121^{\circ} 15^{\prime} \mathrm{E}$ longitude. Distribution of Macassar ebony covers all sites from north to south of the Sulawesi island (Asdar et al. 2015). However, due to over exploitation since 1985, the availability of Maccasar ebony has decreased. Therefore, Indonesian government has developed a plantation program to sustain D. celebica. There are 40 year old of Macassar ebony trees at the Bogor University research plantation. However, data and information on the properties of planted Macassar ebony are not available for its further development and proper utilisation.

When Macassar ebony trees grow into mature wood (age rotations $>80$ years), they are harvested and processed for high quality wood products. However, Macassar ebony trees harvested at age 
rotations below 40 years could be expected to contain a high proportion of juvenile wood. The juvenile portion of the tree stem surrounding the pith is characterised by a progressive change in cell features and wood properties (Evans et al. 2000, Lachenbruch et al. 2011). In comparison with mature wood, juvenile wood is made of smaller and shorter fibres with thinner walls and larger microfibril angles, lower density and lower strength properties (Adamopoulus et al. 2007, Gryc et al. 2011, Fajriani et al. 2013). It is well known that characteristics of juvenile wood contribute to undesirable solid wood properties. Juvenile wood is acceptable for products such as newsprint and quality printing paper (Zobel 1984). However, it may cause serious problems for quality products, especially veneer or solid wood products.

Macassar ebony does not produce distinct growth rings, and can produce more than one growth ring in a year. Detailed information on growth rates and maturation ages of the Macassar ebony are important to obtain a better understanding of its functions. However, little is known about growth rates and maturation age of the Macassar ebony trees. Therefore, investigating the juvenile and mature composition and characterising their properties will lead to better utilisation of Macassar ebony wood.

Macassar ebony wood is classified as durable to termite attack (Martawijaya et al. 2005). Decay resistance can vary according to radial position (distance from pith to bark) from which wood is utilised. In some species, the resistance of the outer heartwood increases markedly from the upper to the lower trunk. Radial differences in resistance can vary significantly, notably in larger trees, with the lowest resistance occurring in the innermost wood (Zabel and Morrell 1992). This rate of resistance has been thought to be influenced by the amount of extractives deposited in the heartwood and sapwood. Therefore, radial variation from pith to bark in terms of extractive content determines the nature of decay resistance of Macassar ebony.

The focus of this study was to characterise the profiles and average trends in density, shrinkage, fibre length, microfibril angle (MFA), modulus of rupture (MOR), modulus of elasticity (MOE), extractive content compound and natural durability of Macassar ebony wood as a function of radial increments from pith to bark.

\section{MATERIALS AND METHODS}

\section{Sample tree origin}

Sample trees were obtained from a research plantation managed by Bogor Agricultural University. The research plantation is located at Darmaga Bogor (6 26' S, $106^{\circ} 48^{\prime}$ E, 145-195 m above sea level), West Java. Darmaga Bogor West Java has an average annual rainfall of $4000 \mathrm{~mm}$ with an average temperature of $25^{\circ} \mathrm{C}$. Three trees were selected from the plantation site as representative specimens. The sample trees were 40 years of age, and had a height of branch-free stem ranging from 12 to $15 \mathrm{~m}$, and average diameter at breast height (DBH) of $30 \mathrm{~cm}(1.3 \mathrm{~m}$ above ground level). After felling the trees, a log section of $2 \mathrm{~m}$ in length was taken from each tree from the middle part of the stem. The sample logs were wrapped in plastic to maintain the green condition before they were transported to the wood workshop for preparation of test specimens.

\section{Specimen preparation}

Considering the fact that growth rings are not present in Macassar ebony, a more practical radial increment method was applied for characterising the juvenile and mature wood (Darmawan et al. 2013). Radial increments were marked from pith to bark and numbered consecutively, as shown in Figure 1. The width of radial increments for fibre length and MFA measurement was $1 \mathrm{~cm}$, and the width for other trait measurements were $2.5 \mathrm{~cm}$. Wood traits (density, shrinkage, fibre length, MFA, MOE, MOR and natural decay resistance) were measured at each radial increment, and used to characterise the juvenile and mature wood of the Macassar ebony.

Three sample disks of $2 \mathrm{~cm}$ thickness (Figure 1-a1) were cross cut from the sample logs using a bandsaw. Other sample of $50 \mathrm{~cm}$ length (Figure 1-b1) were also cut from the rest of the logs. From the al disks, flitches of $2.0 \mathrm{~cm}$ in the radial $(\mathrm{R})$ direction were prepared from bark to bark through the pith using a band saw for fibre length and MFA measurements (Figure 1-a2). The flitches were cut into segments of $1 \mathrm{~cm}$ in the radial direction from pith to bark and numbered conscutively. The individual specimens of $1 \mathrm{~cm} \times 2 \mathrm{~cm} \times 2 \mathrm{~cm}$ [R, tangential 
(T), longitudinal (L) ] for the juvenile mature test (fibre length and MFA) were put in a plastic bag and stored in a refrigerator to keep in green condition (Figure 1-a3). From b1 samples, boards of $2.5 \mathrm{~cm}$ thickness in the tangential direction were band-sawed bark to bark through the pith (Figure 1-b2). The boards were also re-sawn into segments of $2.0 \mathrm{~cm}$ in the radial direction from pith to bark and numbered consecutively. Square boards, for the green moisture content and density tests were put in a plastic bag and stored in a refrigerator. Square boards for air dried test specimens of density, shrinkage, static bending test (MOE/MOR) and decay resistance were carefully stacked to prevent warping, and air dryed at temperature $23 \pm 2{ }^{\circ} \mathrm{C}$ and relative humidity of $80 \pm 5 \%$ (Figure 1-b3).

\section{Density and shrinkage measurement}

Density and shrinkage profiles from pith to bark were measured based on BS 373-1957 testing procedure (BSI 1957). The square boards (Figure 1 -b3) were planed into $2 \mathrm{~cm} \times 2 \mathrm{~cm} \times 6 \mathrm{~cm}$. Density and shrinkage test specimens $(2 \times 2 \times 6 \mathrm{~cm})$ were cut from the planed boards. Five test specimens of each radial increment were used for the measurements. Basic density values from each radial increment were derived and used to calculate the density profiles from pith to bark. Shrinkage after air drying (moisture content
$15 \%$ ) was measured from pith to bark in radial, tangential and longitudinal directions.

\section{Static bending test measurement}

Air dried bending test specimens $(2 \mathrm{~cm} \times 2 \mathrm{~cm} \times$ $30 \mathrm{~cm}$ ), straight-grained and free from any visible defects, were prepared from the planed boards (Figure 1-b3) with true radial and tangential surfaces. The bending test specimens were numbered consecutively from pith to bark. Static bending tests were conducted using the Instron universal testing machine based on BS 373-1957 testing procedure (BSI 1957).

\section{Fibre length and MFA measurement}

Juvenile mature test specimens (Figure 1-a3) were used to characterise fibre length and MFA from pith to bark. Small pieces were prepared from the test sepecimens for maceration based on Schulze's method. The small pieces were treated with nitric acid and a small quantity of potassium chlorate to dissolve the middle lamella and allow the fibres to become separated from one another. Macerated fibre suspension was placed on a microscope slide by means of a needle dropper based on TAPPI T401 om- 88 procedure (TAPPI 1991a). Thirty slides of macerated fibre were prepared from each juvenile and mature test specimen. The slides were then dried and

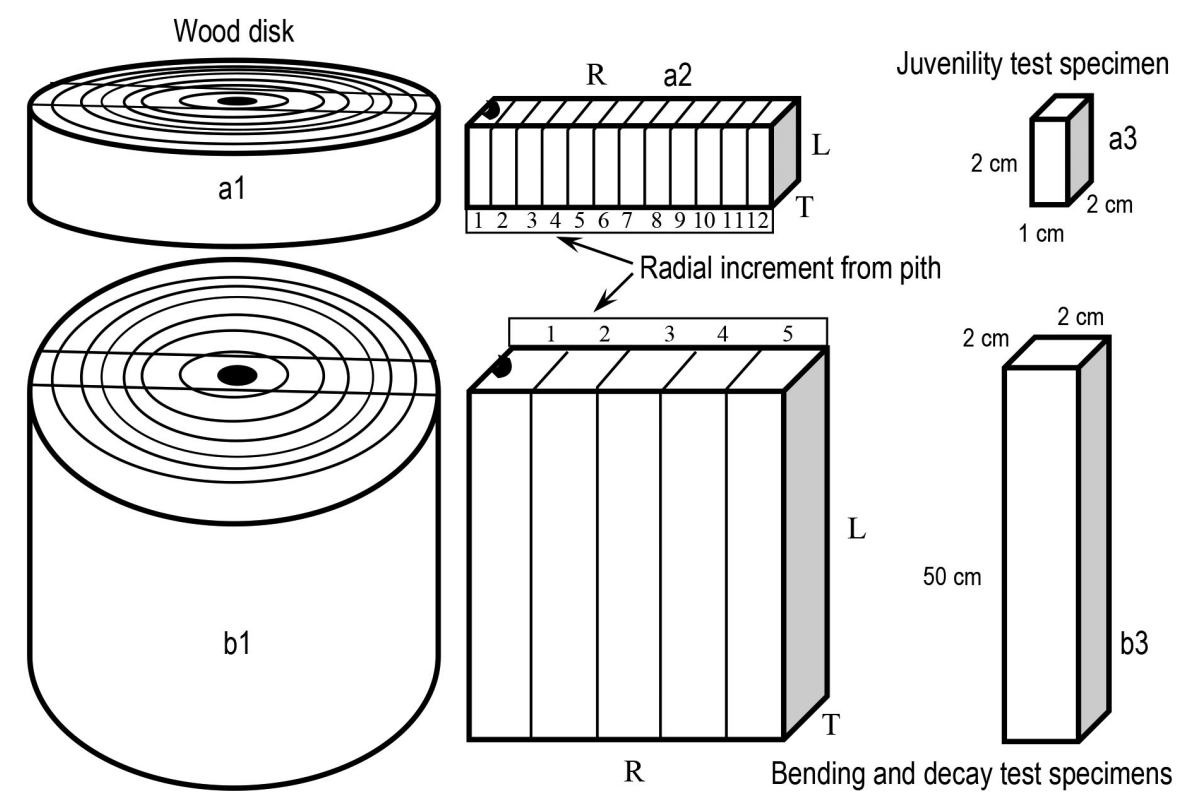

Figure 1 Schematic drawing of the preparation of test specimens; $\mathrm{R}=$ radial, $\mathrm{T}=$ tangential, $\mathrm{L}=$ longitudinal 
a cover glass was placed over the fibre and the fibre length was measured under an optical video microscope. Undamaged single fibres were selected from each slide, and their images were captured. The captured images were analysed using Motic image software for measurement of the fibre length.

The juvenile mature test specimens (Figure 1-a3) were microtomed to produce undamaged thin tangential sections of $30 \mu \mathrm{m}$ thick. Fifteen slides were prepared from each juvenile mature test specimen. The slides were analysed under a polarisation microscope, and cells presenting clear microfibrils were imaged and analysed using Motic image software for measuring the angle of microfibrils.

A segmented regression model was used to determine the transition radial increment from juvenile to mature wood. It is assumed that development of fibre length and MFA from pith to bark can be described by two functions in a curve. The first function is a steep slope of the curve for the first years, beginning at the pith (juvenile wood), and the second function is a constant slope for the later part of the curve (mature wood). The fitted regression model for the functions takes the form of a quadratic model with a plateau. The transition radial increment was directly obtained by using nonlinear least squares procedures (PROC NLIN) in SAS STAT (SAS Institute 2004).

\section{Extractive content measurement}

Extractive content of each radial section from pith to bark was determined by using acetone extraction method. Acetone extractives were extracted from $5 \mathrm{~g}$ of 50 mesh wood powder from each radial section of the Macassar ebony using TAPPI T204 om-88 procedures (TAPPI 1991b). The extractive contents were calculated based on the percentage of extract dry mass to powder dry mass. The acetone extracts of heartwood (radial section 1,2) and sapwood (radial section 4, 5), shown in Figure 2, were analysed at LERMAB, University of Lorraine by gas chromatography mass spectrometry (GCMS) and nuclear magnetic resonance (NMR) to determinine its compounds. Gas chromatography was carried out on a $5 \%$ diphenyl $/ 95 \%$ dimethyl polysiloxane fused-silica capillary column (DB- $5 \mathrm{~ms}, 30 \mathrm{~m} \times 0.25 \mathrm{~mm}$, $0,25 \mu \mathrm{m}$ film thickness) with helium as carrier gas at a constant flow of $1 \mathrm{~mL} \mathrm{~min}{ }^{-1}$. The instrument was equipped with an electronically controlled split/split-less injection port. The injection $(1 \mu \mathrm{L})$ was performed at $250{ }^{\circ} \mathrm{C}$ in the split-less mode. The oven temperature program was as follows: start at $80^{\circ} \mathrm{C}$ for $2 \mathrm{~min}$, increase from 80 to $190^{\circ} \mathrm{C}$ at a rate of $10{ }^{\circ} \mathrm{C} \mathrm{min}{ }^{-1}$, increase from 190 to $280{ }^{\circ} \mathrm{C}$ at a rate of $15{ }^{\circ} \mathrm{C} \mathrm{min} \mathrm{min}^{-1}$ and hold for $5 \mathrm{~min}$, then $10{ }^{\circ} \mathrm{C} \mathrm{min}^{-1}$ until $300{ }^{\circ} \mathrm{C}$ and hold for 40 minutes. Ionisation was achieved under the electron impact mode ( $70 \mathrm{eV}$ ionisation energy). The source and transfer line temperatures were 250 and $300{ }^{\circ} \mathrm{C}$, respectively. Detection was carried out in scan mode of $\mathrm{m} / \mathrm{z}=45$ to $\mathrm{m} / \mathrm{z}=700$. The detector was switched off in the initial 2 min (solvent delay). Compounds were identified by comparison with spectra from National Institute of Standards and Technology (NIST), Gaithersburg, MD, USA mass spectral library (edition 2011).

The ${ }^{1} \mathrm{H}$ 1D NMR spectra were recorded at $27^{\circ} \mathrm{C}$ on a DRX 400 spectrometer, operating at $400 \mathrm{MHz}$. Sixteen transients were collected with an acquisition time of $2 \mathrm{~s}$. Whereas, the ${ }^{13} \mathrm{C} 1 \mathrm{D}$ NMR spectra were recorded at $27^{\circ} \mathrm{C}$ on a DRX 200 spectrometer, operating at $50.34 \mathrm{MHz}$. A total of 1024 transients were collected with an acquisition time of $2 \mathrm{~s}$, and $20 \mathrm{mg}$ of wood extract was dissolved in $0.6 \mathrm{~mL}$ of $\mathrm{CDCl}_{3}$. Solvent signals were used as references at 7.25 and $77.7 \mathrm{ppm}$ for ${ }^{1} \mathrm{H}$ and ${ }^{13} \mathrm{C}$ spectra respectively.



Figure 2 Cross-section of Macassar ebony sample disk showing radial increment numbers 1 and 2 (heart wood), 3 (transition), 4 and 5 (sapwood) 


\section{Natural durability test}

Air dried decay test specimens of $2.0 \times 2.0 \times$ $5.0 \mathrm{~cm}(\mathrm{R}, \mathrm{T}, \mathrm{L})$ were prepared from the planed boards (Figure 1-b3). The test specimens were numbered consecutively from the pith to bark. The termite durability test was carried out according to Indonesian National Standard SNI 07-7207 (BSN-SNI 2014). The wood specimens were evaluated based on average mass loss of the test specimens and mortality of termite. One end of the PVC pipe was plugged into the surface of the wood specimens. Feeding was carried out by placing 50 healthy and active Cryptotermes cynocephalus into the PVC pipes, covered with cotton. The test samples were placed in a room at room temperature $25 \pm 2{ }^{\circ} \mathrm{C}$ and humidity $70 \pm 5 \%$ for 12 weeks. Decay was assessed after 12 weeks and their percent of mass loss due to termite attack and the percent of mortality were calculated. Termite resistances of the samples were rated according to SNI 07-7207 (BSN-SNI 2014) (Table 1).

Table 1 Natural durability of wood against termite based on SNI 01-7207 standard test

\begin{tabular}{|c|c|}
\hline Durability class & Weight loss $(\%)$ \\
\hline Very durable & $<2.0$ \\
\hline II Durable & $2.0-4.3$ \\
\hline III Moderately durable & $4.4-8.1$ \\
\hline IV Slightly durable & $8.2-28.1$ \\
\hline V Not durable & $>28.1$ \\
\hline
\end{tabular}

The wood samples were also tested to evaluate their resistance against decay fungal attack according to SNI 07-7207 standard method (BSNSNI 2014). The dimension of the samples were $2 \mathrm{~cm} \times 2 \mathrm{~cm} \times 2 \mathrm{~cm}(\mathrm{R}, \mathrm{T}, \mathrm{L})$ with 5 replications for each radial section. Wood samples were dried at $103{ }^{\circ} \mathrm{C}$ for $48 \mathrm{~h}$ and their mass were measured. White rot fungus of Schizophyllum commune was inoculated on potato agar culture medium in petri dish and cultivated in an incubator at $22 \pm$ $2{ }^{\circ} \mathrm{C}$ temperature and $70 \pm 5 \%$ of relative humidity for 14 days. After mycelium has permeated the culture disc, wood samples were put in each petri dish and placed in an incubator for 12 weeks. The test samples were removed from the petri dish and were cleaned from attached mycelium. The decay resistances were measured by mass loss in an oven dry state and were rated according to SNI 07-7207 (BSN-SNI 2014) (Table 2).

Table 2 Natural durability of wood against decay fungi based on SNI 01-7207 standard test

\begin{tabular}{lc}
\hline Durability class & Weight loss $(\%)$ \\
\hline I $\quad$ Very durable & $<0.5$ \\
II $\quad$ Durable & $0.5-4.9$ \\
III $\quad$ Moderately durable & $5.0-9.9$ \\
IV $\quad$ Slightly durable & $10.0-30.0$ \\
V $\quad$ Not durable & $>30$ \\
\hline
\end{tabular}

\section{RESULTS AND DISCUSSION}

\section{Density and Shrinkage}

Figure 3a indicates that density increased proportionally from pith to bark. The density at moisture content $29.2 \pm 4.2 \%$ of the Macassar ebony close to the pith was $774.8 \pm 47.5 \mathrm{~kg} \mathrm{~m}^{-3}$, while density at moisture content $54.0 \pm 5.8 \%$ of the tests specimens immediately inside the bark was $907.5 \pm 41.3 \mathrm{~kg} \mathrm{~m}^{-3}$. The average density from pith to bark for green condition was 848.3 $\pm 45.4 \mathrm{~kg} \mathrm{~m}^{-3}$. Martawijaya et al. (2005) found that the air-dry (moisture content $15 \%$ ) density of Macassar ebony wood specimens from natural forest was in the average of $1120 \pm 80 \mathrm{~kg} \mathrm{~m}^{-3}$. The results indicated that the density of the test specimens was below the value reported in literature due to its younger age (40 years). For further development of Macassar ebony plantation, fast-growing provenances or clones can be considered for selection. Matching the provenances for specific site conditions and silvicultural requirements appears to be more important in Macassar ebony improvement programmes.

The variations of air-dried shrinkage for the Macassar ebony from pith to bark are presented in Figure 3b. The mean values obtained for shrinkage of the test specimens in the longitudinal, radial and tangential directions were $0.28 \pm 0.08,3.96 \pm 0.41$ and $5.71 \pm 0.68 \%$. The coefficient of anisotropy (ratio of tangential to radial shrinkage) for Macassar ebony was 1.44. The coefficient indicated that Macassar ebony has a lower degree of anisotropy, which 

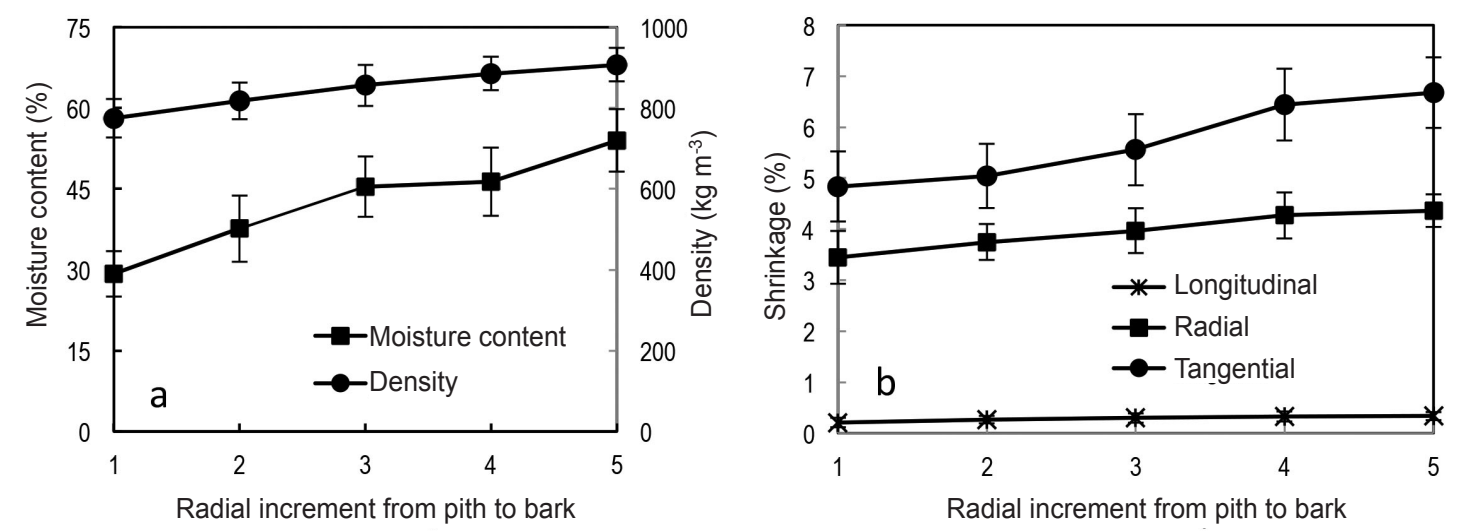

Figure 3 Average density (a) and shrinkage (b) variations from pith to bark for Macassar ebony

leads to improved dimensional stability. Tsoumis (1991) also found that in woods of higher density, the difference between tangential and radial shrinkage is smaller. The high mass (high density) and good stability of Macassar ebony make it a good material option for products such as musical instruments, high-end cabinetry, billiard cues and Japanese butsudan (buddist altar).

\section{Fibre length}

At every radial increment, the length of thirty individual fibres was measured. The results indicated that the fibres varied in length for each radial increment in Macassar ebony. The average values of fibre length at each radial increment were calculated and plotted in a line (Figure $4 \mathrm{a}$ ). The average fibre length values of the first to fifth radial increments were less than $1 \mathrm{~mm}$, whereas in the sixth radial increment it exceeded $1 \mathrm{~mm}$. The mean fibre length value of Macassar ebony started at 706.6 $\pm 53.9 \mu \mathrm{m}$ for the first radial increment. The fibre length increased markedly up to radial increment 6 . From radial increment 6 to the bark, fibre lengths of the Macassar ebony increased gradually. The profile indicated an expected transition of age at a glance. The average fibre length from pith to bark was $1003.1 \pm 68.6 \mu \mathrm{m}$ for Macassar ebony. This finding was close to the value $(1101 \mu \mathrm{m})$ found for Macassar ebony wood from natural forest (Martawijaya et al. 2005).

The PROC NLIN of SAS 9.1.3 was applied for average data to determine juvenile to mature wood transition radial increment (Figure 4a). The model produced by PROC NLIN was a quadratic function of $\mathrm{Y}=-5.85 \mathrm{X}^{2}+95.93 \mathrm{X}+919.37$ and a plateau function of $\mathrm{Y}=1312.64$ at $\mathrm{X}=8.19$,
$\mathrm{R}^{2}=0.99$. The result of this analysis suggested that fibre length was an appropriate trait to determine the transition radial increments of Macassar ebony. The transition by fibre length was estimated to occur at radial increment 8.19 for Macassar ebony wood. The stems of Macassar ebony could contain mature fibres at radial increment 9 (diameter of $18 \mathrm{~cm}$ ). The results indicated that tree stems of Macassar ebony was about $34 \%$ juvenile at the age tested (40 years). This small portion of juvenile wood in the stems of Macassar ebony is important in determining its development in plantation and exploitation for better utilisation.

\section{Microfibril angle}

The average values of MFA in each radial section were calculated and plotted in a line (Figure 4b). Compared to fibre length, the profiles of MFA decreased exponentially from pith to bark. The average MFA values in Figure $4 \mathrm{~b}$ decreased steeply from pith up to radial increment 7 , then decreasesd gradually toward the bark. Beyond the $7^{\text {th }}$ radial increment, the MFA decreased with angles of almost less than $25^{\circ}$. These results suggested that microfibril angles in the stems of Macassar ebony stabilise at values lower than $25^{\circ}$. The MFA would be also an appropriate trait to define the juvenile to mature transition radial increment as with the fibre length. The transition radial increment was also calculated by the segmented regression model. The model produced by PROC NLIN was a quadratic fuction of $\mathrm{Y}=0.37 \mathrm{X}^{2}-5.69 \mathrm{X}+44.47$ and a plateau function of $\mathrm{Y}=22.05$ at $\mathrm{X}=7.7$ with $\mathrm{R}^{2}=0.98$. The transition by MFA was estimated to occur at radial increment 7.7 for Macassar ebony wood. The result suggested that the stems of 

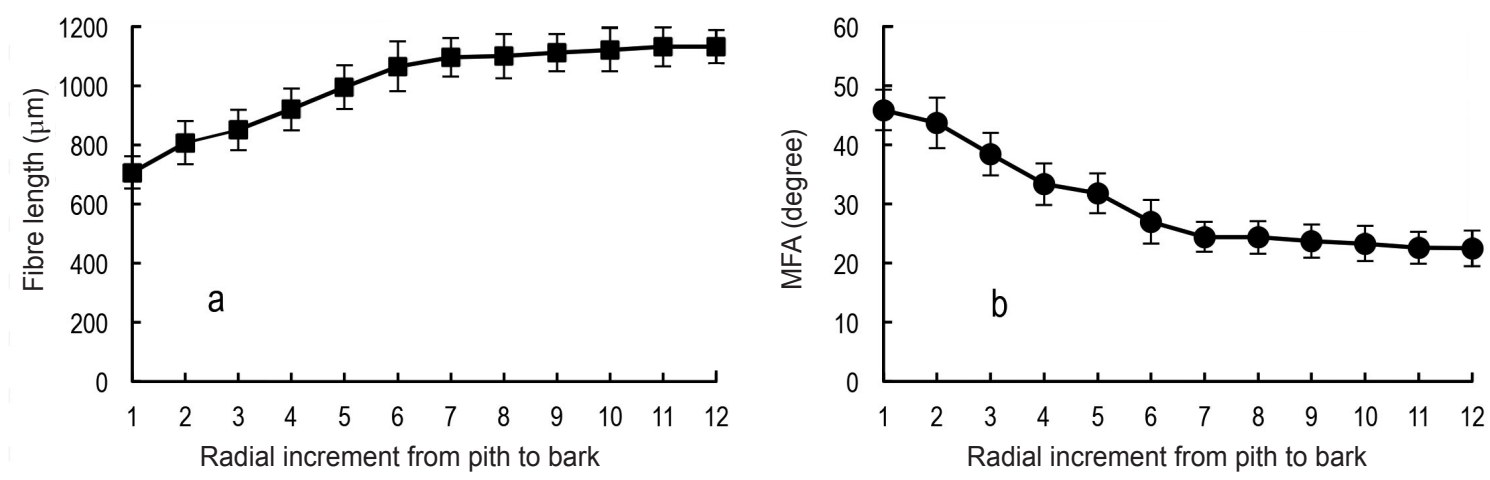

Figure 4 Average fibre length (among 30 individual fibres) and microfibril angle (MFA) (among 15 individual fibres angle) in each radial increment from pith to bark of Macassar ebony wood

Macassar ebony contained mature microfibril angles at radial increment 9 (diameter of $18 \mathrm{~cm}$ ). Therefore, the juvenile wood portions in the stem, based on MFA, were found to be around $34 \%$ for Macassar ebony.

\section{Modulus of elasticity (MOE) and modulus of rupture (MOR)}

The variations of MOE and MOR from pith to bark for Macassar ebony are presented in Figure 5 . The results indicated that juvenile wood of Macassar ebony near the pith had a lower MOE and MOR than near the bark. The lower values of MOE and MOR near the pith were due to larger microfibril angles and lower density. Mean MOE value from pith to bark for Macassar ebony wood was $10,317.5 \pm 705.1 \mathrm{MPa}$, and its mean MOR value was $98.0 \pm 7.9 \mathrm{MPa}$. Martawijaya et al. (2005) showed that the average MOE and MOR of Macassar ebony are 14,709 MPa and $111 \mathrm{MPa}$, respectively. The MOE and MOR values of the Macassar ebony in this study were slightly lower than those of Diospyros crassiflora (MOR $158 \mathrm{MPa}$, $16,890 \mathrm{MPa}$ ), Diospyros ebenum (MOR 128 MPa, MOE 14,070 MPa), Diospyros mespiliformis (MOR $111 \mathrm{MPa}, \mathrm{MOE}$ 11,438 MPa and Diospyros virginiana (MOR $122 \mathrm{MPa}$, MOE 13,858 MPa) (Kukachka 1969). This could be due to the lower age (40 years) of the Macassar ebony compared to others (older than 80 years). However, considering the above results, the mechanical properties of the 40 year old Macassar ebony were comparable.

\section{Extractive content and natural durability}

Extractive, a naturally occurring minor constituent of wood, is essential for the protection of wood from decay by wood destroying organisms. As shown in Figure 6, the acetone extractive content of Macassar ebony decreased from pith to bark. The average extractive content of radial increment number 1 (near the pith) was $12.1 \pm 1.4 \%$, while radial increment number 5 (near the bark) was 4.4
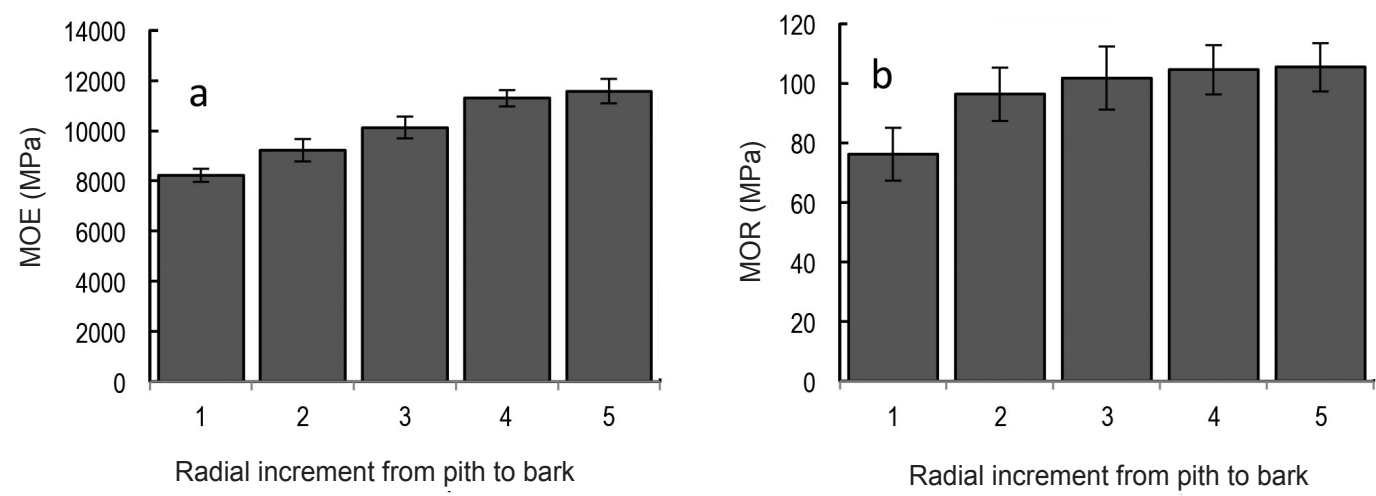

Figure 5 Development of mean of modulus of elasticity (MOE) (a) and modulus of rupture (MOR) (b) from pith to bark of Macassar ebony tree 
$\pm 0.7 \%$. As reported in a previous study, radial variation is also exhibited by ethanol-benzene extractive content. Sapwood tissue possesses the lowest ethanol-benzene extractive content $(2.70 \%)$, while the inner and outer heartwood tissue maintains higher extractive levels, 4.10 and $4.60 \%$ respectively (Stringer and Olson 1987, Gierlinger and Wimmer 2004).

The heartwood (radial increment number 1 and 2) and sapwood (radial increment number 4 and 5), as shown in Figure 2, of Macassar ebony were specific for phenolic compounds (Table 3). Aceton extract by GCMS and NMR showed major compounds such as dimethoxymethylnaphthol, dimethoxymetylnaphtol trimethylsilane and gallic acid trimethylsilane. Though dimethoxymethylnaphthol compounds were not observed in the sapwood of Macassar ebony, gallic acid trimethylsilane were observed in larger amounts. Natural resistance exhibited by Macassar ebony would be due to the presence of dimethoxymethylnaphthol in the heartwood extract, and gallic acid in the sapwood extract.
A study on termite resistance of various timbers found that the heartwood extract of Macassar ebony contains a large amount of dimethoxymethylnaphthol (Sandermann and Dietrichs 1957), which is toxic to termites. In another study, 7-methyl-juglone was found in the wood extract of Diospyros virginiana which is toxic to termites (Carter et al. 1978). Gallic acid has been reported as a toxic compound for decay fungi (Kishino et al. 1995). Natural durability of most heartwood is enhanced by the presence of toxic extractive components which vary with different species, and determine their level of durability (McDaniel 1992, Taylor et al. 2006, Santana et al. 2010).

As Macassar ebony extractive content decreased (Figure 6), the mass loss of sample due to white rot fungi increased, however the mass losses were below $1 \%$. The average mass loss of samples was $0.11 \pm 0.02 \%$ and $0.47 \pm$ $0.07 \%$ near the pith and bark respectively (Figure 7). The wood samples of Macassar ebony near the pith showed slightly higher termite

Table 3 Identified main compounds in the acetone extract of Macassar ebony heartwood and sapwood by gas chromatography-mass spectrometry (GC-MS) and nuclear magnetic resonance (NMR) analysis

\begin{tabular}{cclclc}
\hline \multirow{2}{*}{$\begin{array}{c}\text { Retention } \\
\text { time }(\mathrm{min})\end{array}$} & $\begin{array}{c}\text { Molecular } \\
\text { weight } \\
\left(\mathrm{g} \mathrm{moll}^{-1}\right)\end{array}$ & \multicolumn{1}{c}{ Heartwood } & Abundance & Sapwood & Abundande \\
\cline { 3 - 6 } & 218 & Dimethoxymethylnaphthol & $56.86 \%$ & Dimethoxymethylnaphthol & Not found \\
15.324 & 263 & Unidentified & $24.96 \%$ & Unidentified & Not found \\
15.934 & 290 & $\begin{array}{l}\text { Dimethoxymetylnaphtol } \\
\text { trimethylsilane }\end{array}$ & $16.78 \%$ & $\begin{array}{l}\text { Dimethoxymetylnaphtol } \\
\text { trimethylsilane }\end{array}$ & Not found \\
15.979 & 458 & Gallic acid trimethylsilane & $1.40 \%$ & Gallic acid trimethylsilane & $37.19 \%$ \\
\hline
\end{tabular}

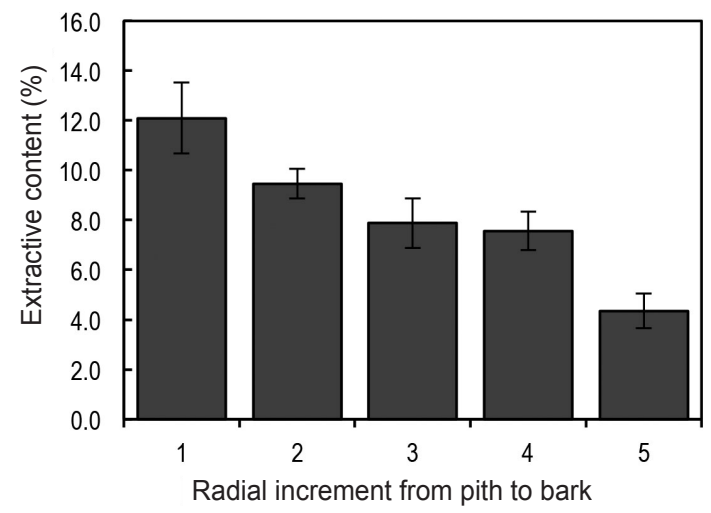

Figure 6 Variation of extractive content from pith to bark of Macassar ebony

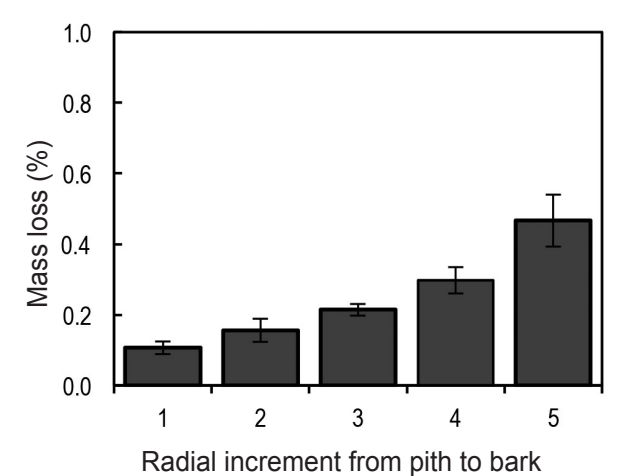

Figure 7 Variation of mass loss due to white rot fungi (Schizophyllum commune) attack from pith to bark of Macassar ebony 

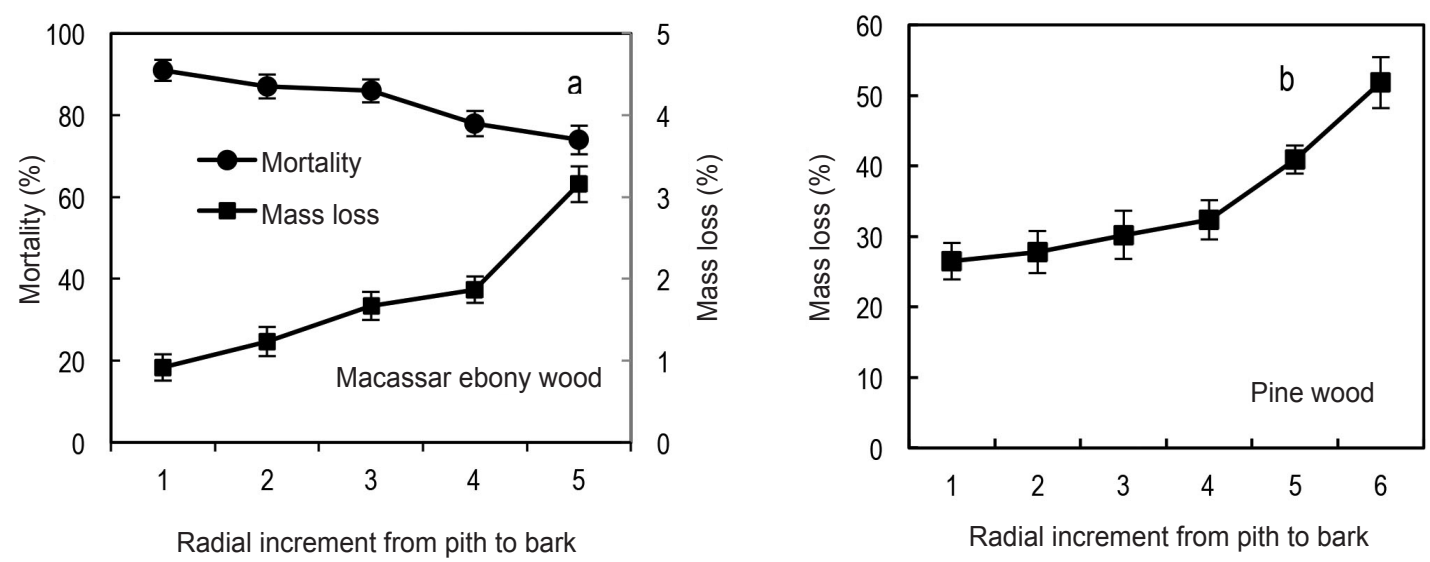

Figure 8 Variation of termite (Cryptotermes cynocephalus) mortality and mass loss of wood samples from pith to bark of Macassar ebony and Pine wood (Pinus merkusii) in laboratory test

resistance, as indicated by lower mass loss $(0.92$ $\pm 0.16 \%)$, and larger termite mortality $(91.0 \pm$ $2.6 \%$ ), than samples near the bark, during three months of the test (Figure 8a). The results in Figure $8 \mathrm{~b}$ show that the average weight loss of non-durable pine wood (Pinus merkusii) was 26 and $51 \%$ near the pith and bark respectively. Both heartwood and sapwood regions of the Macassar ebony were completely resistant from the attack of white rot fungi and $C$. cynocephalus termite. This decay resistance and the above MOE-MOR results indicated that 40 year old Macassar ebony from the plantation would be class I (very good), both in strength and natural durability. The results depict Macassar ebony as relatively low in juvenile portion and superior in shrinkage, strength and durability by the age of 40 .

\section{CONGLUSION}

The portion of juvenile wood in Macassar ebony at the ages tested were $34 \%$. Macassar ebony, at 40 years of age, was a high density wood with very good stability. The static bending strength (MOE/MOR) values of Macassar ebony were classified as class 1. Macassar ebony was also rated as grade 1 for decay resistance against white rot fungi and subterranean termite. The superior characteristics of Macassar ebony wood at 40 years of age would promote its utilisation for high quality and value products. Therefore, the future for Macassar ebony wood developed in plantations should be promising.

\section{ACKNOWLEDGEMENT}

The authors would like to thank the Ministry of Research Technology and Higher Education, RISTEK DIKTI (T/57/D2.3/KK.04.05/ 2019), Republic of Indonesia for world class professor grant.

\section{REFERENCES}

Adamopoulos S, Passialis C \& Voulgaridi E. 2007. Strength properties of juvenile and mature wood in black locust (Robiniapseudo acacia). Wood Fibre Science 39: 241-249.

Asdar M, Prayttno TA, Lukmandaru G \& Faridah E. 2015. Sebaran, potensi dan kualitas kayu eboni (Diospyros Celebica Bakh.) di Sulawesi (distribution, potency and quality of ebony (Diospyros celebica Bakh.) in Sulawesi. Journal of Agroland 22: 94-105.

Beech E, Shaw K, Rivers M \& Schatz GE. 2016. Global Survey of Ex situ Ebony Collections. Botanic Gardens Conservation Internationa, Richmond.

BSN-SNI (BADan Standardisasi Nasional - Standar Nasional INDONESIA). 2014. Uji Ketahanan Kayu dan Produk Kayu Terhadap Organisme Perusak Kayu. BSN-SNI 01-72072014. Badan Standardisasi Nasional, Jakarta.

BSI (British Standards Institution). 1957. Standard Test Methods for Small Clear Specimens of Timber. BS 3731957. British Standards Institution, London.

Carter Fl, Garlo AM \& Stanely JB. 1978. Termiticidal components of wood extracts: 7-methyl-juglone from Diospyros virginiana. Journal of Agricultural and Food Chemistry 26: 869-873. https://doi.org/10.1021/ jf60218a018.

Darmanan W, Rahayu I, Nandika D \& Marchal R. 2013. Determination of juvenile and mature transition ring for fast growing sengon and jabon wood. Journal of the Indian Academy of Wood Science. 10: 39-47. https:/ / doi.org/10.1007/s13196-013-0091-x. 
Evans J, Senft JF \& Green DW. 2000. Juvenile wood effect in red alder: analysis of physical and mechanical data to delineate juvenile and mature wood zones. Forest Products Journal 50: 75-87.

Fajriani E, Ruelle J, Dlouha J, Fournier M, Hadi YS \& Darmawan W. 2013. Radial variation of wood properties of Sengon (Paraserianthes falcataria) and Jabon (Anthocephalus cadamba). Journal of the Indian Academy of Wood Science 10: 110-117. https://doi. org/10.1007/s13196-013-0101-z.

Gierlinger N \& Wimmer R. 2004. Radial distribution of heartwood extractives and lignin in mature european larch. Wood and Fibre Science 36: 387-394.

Griffiths CJ, Hansen DM, Jones CG, Zǚl N \& Harris S. 2011. Resurrecting extinct interactions with extant substitutes. Current Biology. 21: 762-765. https://doi. org/ 10.1016/j.cub.2011.03.042.

Gryc V, Vavrcik H \& Horn K. 2011. Density of juvenile and mature wood of selected coniferous species. Journal of Forest Science. 57: 123-130. https://doi. org/10.17221/18/2010-JFS.

Kishino M, Оhi H \& Yamaguchi A. 1995. Characteristics of methanol extractives from chengal wood and their antifungal properties. Mokuzai Gakkaishi. 41: 441-447.

Kukachka BF. 1969. Properties of Imported Tropical Woods. Pp 117-128 in National Hardwood Lumber Association (ed) Proceedings of the Conference on Tropical Hardwoods. 18-21 August, the State University College of Forestry, Syracuse University, Syracuse, New York.

LACHenbruch B, MoORe JR \& Evans R. 2011. Radial variation in wood structure and function in woody plants, and hypotheses for its occurrence. Size and age-related changes in tree structure and function. Tree Physiology 4: 121-164. https://doi.org/10.1007/978-94-0071242-3_5.

Martawijya A, Kartasujana I, Kadir K \& Prawira S. 2005. Atlas Kayu Indonesia. Forest Products Research Institute, Bogor.

MCDANIEL CA. 1992. Major antitermitic components of the heartwood of southern catalpa. Journal of Chemical Ecology 18: 359-69. https://doi.org/10.1007/ BF00994237.
Orwa C, Mutua A, Kindt R, Jamnadass R \& Anthony S. 2009. Agroforestry Database: A Tree Reference and Selection Guide. Version 4.0. World Agroforestry Centre, Kenya.

Sandermann W \& Dietrichs HH. 1957. Begleitstoffe - ursache der eigenart der holzer. Ergebnisse papierchomatographischer untersuchungen. Umaschau. 197-200.

Santana AlbD, Maranhão CA, Santos JC, Cunha FM, Conceição GM, Bieber LW \& Nascimento MS. 2010. Antitermitic activity of extractives from three Brazilian hardwoods against Nasutitermes corniger. International Biodeterioration E Biodegradation 64: 7-12. https://doi.org/10.1016/j.ibiod.2009.07.009.

SAS Institute. 2004. SAS/STAT9.1 User's Guide. $1^{\text {st }}$ Edition. SAS Institute Incorporation., Cary.

STRINGER JW \& OlSON JR. 1987. Radial and vertical variation in stem properties of juvenile black locust. Wood Fibre Science. 19: 59-67.

TAPPI (Technical Association of Pulp and Paper Industry). 1991a. Tappi Test Methods: Morphological Characteristics of Pulp Fibre Under Microscope. T 401 om-88. Tappi Press, Atlanta.

TAPPi (Technical Association of Pulp and Paper Industry). 1991b. Tappi Test Methods: Solvent Extractives of Wood and Pulp. Tappi Press, Atlanta.

Taylor AM, Gartner BL \& Morrell JJ. 2006. Efects of heartwood extractive fractions of Thuja plicata and Chamaecyparis nootkatensis on wood degradation by termites or fungi. Jornal of Wood Science 52: 147-153. https://doi.org/10.1007/s10086-005-0743-6.

Tsoumis G. 1991. Science and Technology of Wood: Structure, Properties, Utilization. Van Nostrand Reinhold, New York.

WALLnÖfER B. 2001. The biology and systematics of Ebenaceae: a review. Annalen des Naturhistorischen Museums in Wien. Series B, Für Botanik und Zoologie. 485-512.

ZoBEL BJ. 1984. The changing quality of the world wood supply. Wood Science Technology. 18: 1-7. https://doi. org/10.1007/BF00632127.

Zabel RA \& Morrell JJ. 1992. Wood Microbiology-Decay and Its Prevention. Academic Press, New York. 